\title{
Parenting Local Community Culture to Build Moral and Social Children
}

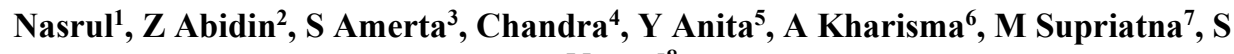 \\ Nasrul $^{8}$ \\ 1,2,3,4,5 Universitas Negeri Padang, Padang \\ ${ }^{6,7}$ Universitas Pendidikan Indonesia, Bandung \\ ${ }^{8}$ Sekolah Tinggi Keguruan Ilmu Pendidikan Adzkia, Padang \\ ${ }^{1}$ nasrul@fip.unp.ac.id, ${ }^{2}$ zainalabidin@fip.unp.ac.id, ${ }^{3}$ sriamerta@fip.unp.ac.id, \\ 드andra@,fip.unp.ac.id, ${ }^{5}$ yesianita@fip.unp.ac.id, ${ }^{6}$ annisakharisma@upi.edu, \\ ․ㅡa2t.supri@upi.edu ${ }^{8}$ silviananasrul@gmail.com
}

\begin{abstract}
The value of cooperation is difficult to find in elementary school-age children due to digital influences in the era of industrial revolution 4.0. The purpose of the research is to examine the value of cooperation that is contained in the smart to produce learning models. The research method applied was qualitative research with the style of grounded theory. The results showed that the value of collaboration can be seen from the activities of music players with players in circles, music games with movements in circles, music players with the movements of characters, and between characters. The study of the value of collaboration in learning is useful for creative ideas in basic education. The theory produced in this study, namely smart games can be used as the latest drama learning method based on local wisdom in elementary schools that can build the value of student collaboration.
\end{abstract}

Keywords: Randai, Collaborative Value, Moral, Parenting, Social, Local Wisdom

\section{INTRODUCTION}

West Sumatra has been inhabited by most Minangkabau tribes. The Minangkabau tribe has a variety of cultures that are still preserved to this day, namely the culture of clothing, music, dance, songs, houses, and games offenses. One of the Minangkabau cultures is the traditional game of the Minangkabau children, namely randai. Randai game can be regarded as one of the art icons in Minangkabau. Randai games not only wrestled by children of the village, now has entered the international world. Even randai games have been made compulsory curriculum in Hawaii, United States, and Manoa.

Randai games are held in various traditional activities. In almost every implementation of various traditional ceremonies in Minangkabau culture, the greatness and grandeur of the implementation of the ceremony are always marked by carrying out randai performances. Starting from the coronation ceremony and inheritance of traditional titles, circumcision, marriage, to the peak events of various youth activities and other formal activities in each village in the Minangkabau community. Randai popularity indicates that randai is an important part of the Minangkabau community. This can be seen from the emergence of Randai groups in almost every corner in the Minangkabau region. Referring to the data collection conducted by the Indonesian National Art Coordinating Agency, West Sumatra Province in 1994, there were 
approximately 250 active randai groups that were spread throughout the province of West Sumatra. Even some area have more than one randai group. These data increasingly show the importance of randai in the Minangkabau community in West Sumatra.

Randai is also assumed to have educational values as parenting that deserves to be studied [1]-[5]. Like communication between characters in randai, communication between musicians and characters. It also needs to be examined more deeply in the value of education that deserves to be emulated in the process of randai games. Randai which characterizes the people of the West Sumatra region began to be influenced by outside cultures. Randai has experienced a lot of innovation and development in various aspects of Randai. So that the classical level possessed by Randai Minangkabau already has renewal. This problem needs to be studied more seriously to maintain the originality of the local culture from the influence of outside cultures. Regarding the importance of randai in the Minangkabau community and the large interest of outside communities with randai culture is an interesting phenomenon to be studied. The purpose of this study is to produce a new theory that randai can be used as a new learning model based on local wisdom to build character values in primary schools so that Indonesian culture remains and is used throughout the life of his heir. Randai is a traditional theater art in the form of children's games in Minangkabau, populist in nature, played in groups with movements in a circle, then slowly moving while conveying stories through singing, alternately combining music, singing, dance, drama, and martial arts into martial arts. one [6][11].

Randai lives with traditions that apply in the Minangkabau community. Randai is present along with the ceremonies and events in the traditional Minangkabau community which are generally exhibited in the context of traditional ceremonies or festivals. The presentation is carried out with a dialogue delivered by dendang or gurindam. The musical accompaniment in the randai performance consisted of puput rice stems, talempong, drum, and tambourine. The performance was performed in an arena with a circular audience formation [7], [9]. Analysis of studies on randai has an extraordinary impact on the development of education in Indonesia, especially in West Sumatra. The contribution of the research conducted produced a learning model based on local wisdom that can build the character of elementary school children. The resulting learning model has a positive influence on elementary school students, in addition to building positive character, it can also reintroduce students to the local culture in their neighborhood.

\section{RESEARCH METHOD}

The research method that has been used is the analysis of literature studies and field studies with the type of qualitative research conducted is Grounded Research. The study was conducted with the beginning of the literature analysis activities so that the theory construction process or categorization through analysis and the process of abstracting research findings. Next, reconstruct the interpretation and interpretation of the results of the research based on the conceptualization of the community which is the subject of the study. The qualitative research procedure using the grounded theory method consists of several stages, namely: (1) the stage of problem formulation, (2) the stage of using theoretical studies (if necessary), (3) the stage of data collection and sampling, (4) the stage of data analysis, and (5) the conclusion or report writing stage [12]. Research data were collected through observation, interviews, and documentation studies. Interviews were carried out on randai experts, character experts, community leaders involved in randai, namely the elder (datuk or niniak mamak) and randai actors, namely people involved in randai games. 


\section{RESULTS AND DISCUSSION}

Randai is etymologically derived from Arabic ra'yanandda'I which is regulated in ra'yanda'i. Ra'yan means vision or observation. While Da'i means preachers, people who call for Islam [13]. In Minangkabau, randai is the name of a folk art form, but not theater. At first, randai was a form of dance. Steps and movements such as pencak, playing in a circle, and an unspecified number of participants [14]. There is no story in this randai, only a poem. Form of randai art used to be only played by teenage boys. Randai is always played on the floor with a circular pattern because it is related to the socio-cultural culture of the Minangkabau. Randai is not played at home or indoors, but on the ground, in the yard, in the fields, or large building spaces [15].

Two main elements form the basis of randai, namely: first, the element of storytelling. The two elements of behavior and movement are conveyed through movements in a circle [16]. The story presented is kaba, and is conveyed through gurindam, drums, and songs. Randai stories are often accompanied by traditional Minang musical instruments, namely salung, rebab, bansi, tambourine or others, and also through dialogue. Based on the kaba circulating and developing in the Minangkabau region, many stories are expressed into Randai art, one of which is Randai Sabai Nan Aluih [16]. The elements of behavior and movement, or dance, are sung through galembong. The dance movements used are based on the movements of the Minangkabau traditional martial arts, with various variations about the martial arts styles in each region. Cast in randai, namely carrier galembong, gorai, drummer, music player, and cast of the story [13], [14], [16].

Randai game starts with making a line. All Randai players marched into the performance arena including the drummer and galembong player. Galembong players enter the arena by making movements. When the offering ceremony is over, the galembong bearers shout "hep ta hep ta: and so on until they form a circle formation," hep ta "is the code and tempo in playing randai. Furthermore, the presentation of the story accompanied by gurindam with drama dialogue in a circular circle. From the beginning to the end of the story gurindam and drama dialogue alternately [17]. The activity continues with all the players taking their respective positions. Music players usually sit close to the sword. Legaran players enter the arena of the middle part of the show by forming two lines and making moves.

Randai games are usually sung by many people by making circles. All of these martial arts movements were carried out guided on cue by one of the legaran players. When the offering ceremony is over, the galembong carriers shout "Hep ta hep ta" by the gorai and so on until they form a circle formation. "Hep ta" is the code and tempo in playing randai.

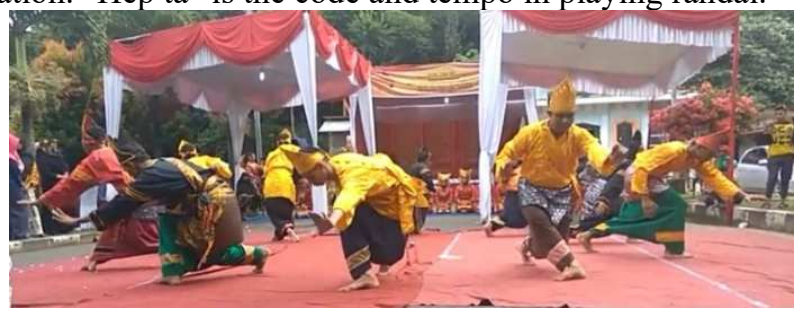

PICTURE 1. Movement in Randai

One of the most important randai moves is to reduce the circle. Randai continued with forming a small circle formation. A small circle formation is formed aiming to deliver the drama performer to convey kaba in the middle of the circle. After the cast is in a circle, randai members 
enlarge the circle again. The next randai process, legaran players return to form a large circle. The way players enter the circle varies. There is also a way to wait after the last player returns to form a large circle and sit in the arena, after which the drama player enters into the middle. The presentation of the story is accompanied by gurindam with drama dialogue in a circular circle. Legaran in randai becomes very important because in legaran the drama players play their respective roles [18]. Circle or legacy randai functions as an introduction to the play in the next round [15].

Based on the results of data analysis interviews with randai players, opinions of community leaders, and West Sumatra cultural figures, Azrul Jamaan Datuk Endah Nan Kuniang stated that the processes and activities in randai if sorted can be designed as follows, namely: making a line with two lines, forming a large legaran, forming a small legend, forming a large legend, drama, forming a small legend, forming a large legend, drama, forming a small legend, forming a large legend, and so on until the drama in randai finished closed by re-forming a line. If sorted simply can be in the following order.

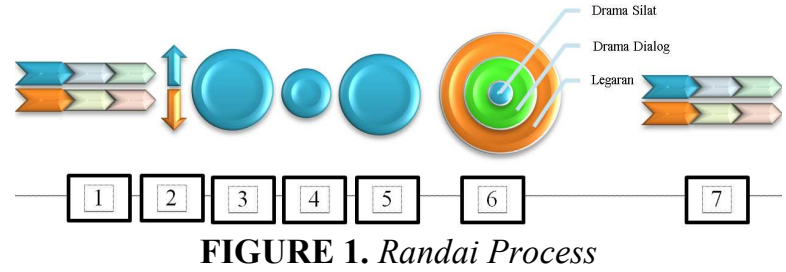

This picture description, namely: (1) making a line, (2) forming two parts, (3) forming a large legaran, (4) forming a small legaran, (5) forming a large legaran, (6) drama, and (7) making the line up. The randai play process above is assumed to be used as discussion material for educational innovation as a basic form of learning steps in basic education. Development research needs to be done as an applied form of randai process into learning steps in basic education. The randai process which is used as an innovation in the learning step will have its usability because in the randai process it teaches players to master the value of cooperation. the value of cooperation is an urgent need that is feared by today's children preoccupied with technology.

Minangkabau traditional art, in general, depicts the nature of cooperation. The nature of cooperation can be seen from randai movements [6], [8], [19]. Collaboration is a synergy of strengths of several people in the form of social interaction efforts, in which there are certain activities aimed at achieving common goals that have been determined through the division of tasks, not as a task force, but as a work unit all of which are directed towards the achievement of goals with help each other and understand each other's activities [20]-[23]. Research shows that in the field of human activity and efforts if done in collaboration with groups, it will lead to better efficiency and effectiveness [21], [24], [25].

Teamwork is a necessity in realizing work success. Teamwork will be a driving force that has energy and synergy for individuals who are involved in teamwork. Without good cooperation will not bring bright ideas. Cooperation will unite the power of ideas that will lead to success [1], [20], [26]. The concepts of teamwork aspects include the unity of individual efforts to produce a performance that is higher than the amount of work process output around the team. Teamwork involves commitment, competence, and general goals. To work well together, there are several stages in common, namely: the similarity of place, mind, feeling, and soul [2], [20], [27]. The purpose of working together is to develop high levels of thought, important communication skills, increase interest, confidence, social awareness and tolerance 
for individual differences. The main basis in this collaboration is expertise, where each person who has different skills, work together into one group/group in completing a job [3], [22], [28].

Educational values in Indonesia are sourced from religion, Pancasila, and culture, as well as national education goals [29], [30]. Values of education according to the center of the curriculum of cultural development and education and national character in 2009, namely: (1) religious. (2) honest, (3) tolerance, (4) discipline, (5) hard work, (6) creative, (7) independent, (8) democratic, (9) curiosity, (10) national spirit, (11) love for the motherland, (12) respect for achievement, (13) friendly and communicative, (14) love for peace, (15) love reading, (16) care for the environment, (17) care for the social, (18) responsibility nationally contains friendly and communicative values at point 13 . Friendly and communicative in question are attitudes and actions that show a sense of pleasure in talking, associating, and cooperating with others [31], [32].

Universally various characters are formulated as values of living together based on pillars: peace, respect, cooperation, freedom, happiness, honesty, humility, compassion, responsibility, simplicity, tolerance, and unity. [33], [34]. The national character values include (1) love for God and the universe and its contents; (2) responsibility, discipline and independence; (3) honest; (4) respect and courtesy; (5) love, care and cooperation; (6) confident, creative, hard work and never give up; (7) justice and leadership, good and humble; and (9) tolerance, peace and unity [35], [36].

The above details show that the position of the value of cooperation in universal value classification is at point 3 and implicit in the national education goal at point 13, namely the friendly and communicative values in which it outlines various values, one of which is the value of cooperation. Whereas according to one expert stated that the position of the value of cooperation in the classification of values is in the 4th order. That is, the value of cooperation is contained in the value classification. Based on the analysis of the research trends carried out, it can be seen that from 2009 to 2012 the object of research studies conducted focused on the application of cooperative learning models in increasing the value of collaboration with experimental research methods. Whereas in 2013 to 2017 showed that research focused on the object of the problem of the influence of collaboration between parents and teachers on the discipline of students and know the magnitude of collaboration between students' parents and teachers in schools [5], [24], [30], [37]-[39]. The study was conducted with the type of experimental and qualitative research models. Next in 2018 until now the research focus on the object of study the effect of the use of randai-based confidence in the ability of elementary students' drama appreciation with experimental research models and produce research results show there is a significant influence on the use of randai-based confidence media as a technique for learning drama appreciation and character-building trust student self. From these findings, the use of rational learning techniques based on confidence in learning drama appreciation and the formation of confident character is highly recommended for use in learning Indonesian in elementary school.

\section{CONCLUSIONS}

Based on the randai study in the discussion, it can be concluded that the randai game is a traditional theater art in the form of children's games in Minangkabau which are populist, played in groups with movements in a circle, then slowly move while conveying stories through singing alternately combining music, singing, dance, drama and martial arts become one. Two main elements form the basis of randai, namely: first, the element of storytelling is about the story used in randai. The two elements of behavior and movement are delivered through galembong, 
namely the bearer of galembong, gorai, drummer, music player, and actor of the story. Randai process, namely: making a line, forming two parts, forming a Big Legaran, forming a Small Legaran, forming a Big Legaran, drama, and making a line. Values in randai, namely the value of cooperation, religious values, the value of discipline, the value of caring, and the value of honesty. The value of cooperation is the main value in randai. The theory generated in the research that has been carried out, namely the upbringing of Minangkabau tribes through randai games can educate children to have a good cooperation. The second theory, namely the process of randai games can be used as a new learning model in the world of primary school education.

\section{REFERENCES}

[1] J. A. Nelson, B. P. Boyer, O. A. Smith, and D. L. Villarreal, "Relations between Characteristics of Collaborative and Oppositional Mother-Child Conflict," Parenting, vol. 19, no. 3, pp. 203-216, 2019.

[2] J. L. Borelli, "The Past is Present: Responses to Infant Crying Among Mothers High in Attachment Anxiety," Parenting, vol. 19, no. 1-2, pp. 22-25, 2019.

[3] J. Parish-Morris, "It Takes Two to Tango: Multi-Directional, Dynamic Influences on Parenting Behavior," Parenting, vol. 19, no. 1-2, pp. 160-163, 2019.

[4] G. Esposito and M. H. Bornstein, "Parenting and Infant Cry," Parenting, vol. 19, no. 12, pp. 1-4, 2019.

[5] K. K. Y. Wong and G. Esposito, "The Unexpected for the Expecting Parent: Effects of Disruptive Early Interactions on Mother-Infant Relationship," Parenting, vol. 19, no. $1-2$, pp. 124-129, 2019.

[6] A. S. Bin Kechot, "Laporan Kajian Randai Warisan Masyarakat Minang Negeri Sembilan: Meneroka Perkembangan dan Taburannya," J. Melayu, vol. 4, no. 4, pp. $161-$ 172, 2009.

[7] S. C. Bangun, S. Zebua, and J. R. Manua, SMA/MA SMK/MAK Kelas. 2014.

[8] M. M. Putri, Desfiarni, and Darmawati, "Pelestarian Kesenian Randai di Sanggar Minang Saiyo Desa Sijantang Kota Sawahlunto," E-Jurnal Sendratasik FBS Univ. Negeri Padang, vol. 4, no. 1, pp. 38-43, 2015.

[9] E. Santosa, H. Subagiyo, H. Mardianto, N. Arizona, and N. H. Sulistiyo, Seni Teater JIlid I. 2008.

[10] M. Riani, "MERAWAT TRADISI DALAM KESEDERHANAAN: Limpapeh Rumah Nan Gadang Tempat," in Kompilasi Karya Pemenang Lomba: Artikel dan Karya Jurnalistik Serta Foto Pendidikan dan Kebudayaan, 2018, vol. 84, pp. 487-492.

[11] H. Minarti, Y. A. Tajudin, and D. I. Gesuri, Ekonomi Kreatif: Rencana Pengembangan Pertunjukkan Nasional 2015-2019. 2015.

[12] I. G. A. N. Budiasih, "METODE GROUNDED THEORY DALAM RISET KUALITATIF," J. Ilm. Akunt. dan Bisnis, vol. 9, no. 1, 2014.

[13] D. P. Putri, "Makna Simbolik Randai Sebagai Kesenian Masyarakat Minangkabau di Kota Payakumbuh Provinsi Sumatera Barat," Jom FISIP UR, vol. 2, no. 2, pp. 1-15, 2015.

[14] Y. Primadesi, "Preservasi Pengetahuan dalam Tradisi Lisan Seni Pertunjukan Randai di Minangkabau Sumatera Barat," J. Kaji. Inf. Perpust., vol. 1, no. 2, pp. 179-187, 2013.

[15] F. Purnama, "Game Sebagai Media Alternatif Pengenalan Permainan Tradisional Randai Minangkabau," Visualita, vol. 6, no. 1, 2014.

[16] Y. Wulandari, "RANDAI SEBAGAI KOMUNIKASI SASTRA DAERAH DI MINANGKABAU : Sebuah Gagasan Melestarikan Budaya Indonesia," in Konferensi 
Nasional Bahasa dan Sastra III, 2014, pp. 633-636.

[17] Zulkifli, "RANDAI SEBAGAI TEATER RAKYAT MINANGKABAU: ALTERNATIF PEMBINAAN DAN PENGEMBANGAN," J. Tari, vol. 1, no. 9, pp. 30-45, 2013.

[18] S. Rustiyanti, "Seni Tradisi Randai Dengan Pembacaan Masa Kini: Kontinuitas dari Tradisi Ke Kontemporer," in SEMINAR NASIONAL RISET INOVATIF II, 2014, p. 747.

[19] H. Syuriadi, H. Hasanuddin, and N. A. Manaf, "Educational Values in Text Stories Randai 'Malangga Sumpah' Workshop Bustami Group Randai Bintang Tampalo Kenagarian Padang Laweh District Sijunjung," Ling. Didakt. J. Bhs. dan Pembelajaran Bhs., vol. 8, no. 1, p. 1, 2018.

[20] D. Widyaningtyas and M. Farid, "Pengaruh Experiential Learning Terhadap Kepercayaan Diri dan Kerjasama Tim Remaja,” Pers. J. Psikol. Indones., vol. 3, no. 03, pp. 237-246, 2014.

[21] E. Nurnawati, D. Yulianti, and H. Susanto, "Peningkatan Kerjasama Siswa SMP Melalui Penerapan Pembelajaran Kooperatif Pendekatan Think Pair Share," Unnes Phys. Educ. J., vol. 1, no. 1, pp. 1-7, 2012.

[22] E. T. Maasawet, "Meningkatkan Kemampuan Kerjasama Belajar Biologi Melalui Penerapan Strategi Inkuiri Terbimbing Pada Siswa Kelas Vii Smp Negeri Vi Kota Samarinda Tahun Pelajaran 2010/ 2011,” BIOEDUKASI (Jurnal Pendidik. Biol., vol. 2, no. 1, 2017.

[23] T. Umar, "Pengaruh Outbound Training Rasa Percaya Diri, Kepemimpinan dan Kerja Sama Tim," pp. 1-10, 2010.

[24] D. M. Zeifman and A. A. Baird, "A Glimpse into the Minds of Mothers: The Default Mode Network and Responsiveness to Infant Cries," Parenting, vol. 19, no. 1-2, pp. 90-93, 2019.

[25] D. Hiraoka, M. Miyasaka, and M. Nomura, "Spousal Presence Modulates Salivary $\alpha$ Amylase Responses to Infant Cry in Mothers With High Attachment Insecurity," Parenting, vol. 19, no. 1-2, pp. 5-21, 2019.

[26] L. M. River, J. L. Borelli, and S. K. Nelson-Coffey, "Tolerance of Infant Distress Among Working Parents: Examining the Roles of Attachment Anxiety and WorkFamily Conflict," Parenting, vol. 19, no. 1-2, pp. 137-159, 2019.

[27] S. W. Setiyanti, "Membangun Kerjasama Tim (Kelompok)," J. STIE SEMARANG, vol. 4, no. 3, pp. 59-65, 2012.

[28] A. L. Greil, J. McQuillan, A. R. Burch, M. H. Lowry, S. M. Tiemeyer, and K. S. Slauson-Blevins, "Change in Motherhood Status and Fertility Problem Identification: Implications for Changes in Life Satisfaction,” J. Marriage Fam., 2019.

[29] D. Siregar, "PENGARUH PEMBELAJARAN PENDIDIKAN KEWARGANEGARAAN MENGGUNAKAN METODE SOSIODRAMA TERHADAP KEPEDULIAN SOSIAL SISWA KELAS V DI SD NEGERI 060898 MEDAN," Elem. Sch. J. PGSD FIP UNIMED, vol. 8, no. 1, pp. 103-109, 2018.

[30] H. Laurent, "Challenges in Characterizing the "Mommy Brain," Parenting, vol. 19, no. 1-2, pp. 94-96, 2019.

[31] H. Syuriadi, H. WS, and Ngusman, "NILAI-NILAI PENDIDIKAN DALAM TEKS CERITA RANDAI 'MALANGGA SUMPAH' KARYA LUKMAN BUSTAMI GRUP RANDAI BINTANG TAMPALO KENAGARIAN PADANG LAWEH KABUPATEN SIJUNJUNG,”, J. Bahasa, Sastra dan Pembelajaran, vol. 2, no. 2, 2014.

[32] Hendrizal and Chandra, "Preliminary Research Description In Developing Tematics Learning Materials by Using Character Building and Discovery Learning to Establish 
Children aged 6-9 Years," Int. Conf. Early Child. Educ., vol. 169, pp. 95-101, 2018.

[33] D. Balliet, C. Parks, and J. Joireman, "Social Value Orientation and Cooperation in Social Dilemmas : A Meta-Analysis,” Gr. Process. Intergr. Relations 2009, vol. 12, no. 4, pp. 533-547, 2009.

[34] Halimatussakdiah, "SOCIAL ETHICS AND LEARNING ATTITUDES OF FISHERMEN'S CHILDREN IN HAJORAN VILLAGE, SUB-DISTRICT OF PANDAN REGENCY OF CENTRAL TAPANULI," Elem. Sch. J. PGSD FIP UNIMED, vol. 7, no. 2, pp. 191-197, 2017.

[35] A. Ghufron, "Integrasi nilai-nilai karakter bangsa pada kegiatan pembelajaran," Cakrawala Pendidik., pp. 13-24, 2010.

[36] Muhammadi, Taufina, and Chandra, "LITERASI MEMBACA UNTUK MEMANTAPKAN NILAI SOSIAL SISWA SD,” LITERA, vol. 17, no. 2, pp. 202-212, 2018.

[37] E. Roellke, M. Raiss, S. King, J. Lytel-Sternberg, and D. M. Zeifman, "Infant Crying Levels Elicit Divergent Testosterone Response in Men," Parenting, vol. 19, no. 1-2, pp. 39-55, 2019.

[38] A. Bentenuto and P. Venuti, "From Supporting to Co-Parenting: The New Roles of Fathers," Parenting, vol. 19, no. 1-2, pp. 30-33, 2019.

[39] C. Hechler, R. Beijers, M. Riksen-Walraven, and C. de Weerth, "Prenatal Predictors of Postnatal Quality of Caregiving Behavior in Mothers and Fathers," Parenting, vol. 19, no. 1-2, pp. 101-119, 2019. 